\title{
KONSEP KAFA'AH MENURUT SAYYID USMAN
}

\author{
Eka Suriansyah, Rahmini
}

\begin{abstract}
This paper examines the concept of kafa'ah according to the thoughts of Sayyid 'Usmdn bin Yahya in the book al-Qawanin asy-Syar'iyyah. The topic of the problem in this paper is the gap between the concept that Sayyid' Usman describes the kafaah and ideally the kafaah concept contained in the Qur'an and hadith. Thus, the purpose of this paper is none other than to know and describe the concept of kafa'ah in marriage according to the thought of Sayyid Usman bin Yahya in the book al-Qawanin asySyar'iyyah. To find out and describe the relevance of the concept of kafa'ah in marriage between saripah and non-sayid according to the thoughts of Sayyid 'Uémdn bin Yahya in the book al-Qawin al-Syar'iyyah with the current situation. Ending this paper shows that the concept of kafa'ah in the marriage of saripah with non-sayid according to Sayyid 'Us'man bin Yahya's thought in the book al-Qawanin ash-Syar'iyyah is not permissible or unlawful, as well as the fatwa which allows saripah marriage with non-sayid. As an argument that reinforces the opinion of Sayyid 'Usman is an opinion taken from two books entitled Bugiyyah al-Musytarsyidin by Sayyid 'Abdurrahman Ba'alawi and Tarsyikhul Mustafdin Bitausihi Fath al-Mu'in by Sayyid' Alawi bin Ahmad al-Saqdf. However, these two opinions were largely motivated by the traditions of the Hadramaut community at the time, and Sayyid 'Usman himself only accepted the law he had taken from the previous ulama who had issued a fatwa first, in this case there was no new ijtihad by Sayyid' Usman. In addition, Sayyid 'Usman also stated several hadiths which were used as arguments for texts which strengthened his opinion, but these hadiths were not at all related to the kafa'ah context. Further developments, it turns out that the thought of Sayyid 'Us'man is no longer relevant to the current situation, besides because Sayyid' Usman's thoughts are more exclusive, this is also because the existence of kafa'ah in a marriage is nothing but to achieve harmony in the home ladder, so that the provisions of the kafa'ah can apply according to the situation and conditions of the people who need it, without having to burden one party and clearly must be separated from personal interests.
\end{abstract}

Keywords: kafa'ah, sarifah and non-sayyid

ABSTRAK

Tulisan ini mengkaji tentang konsep kafa'ah menurut pemikiran Sayyid 'Usmdn bin Yahya dalam kitab al-Qawanin asy-Syar'iyyah.Yang menjadi topik masalah dalam tulisan ini adalah adanya kesenjangan antara konsep yang dipaparkan Sayyid 'Usman mengenai kafaah dengan idealnya konsep kafaah yang tertuang dari al-quran dan hadis. Dengan demikian, tujuan dari tulisan ini tidak lain adalah untuk mengetahui dan mendeskripsikan konsep kafa'ah dalam perkawinan menurut pemikiran Sayyid Usman bin Yahya dalam kitab al-Qawanin asySyar'iyyah. Untuk mengetahui dan mendeskripsikan relevansi konsep kafa'ah dalam perkawinan antara saripah dengan non-sayid menurut pemikiran Sayyid 'Uémdn bin Yahya dalam kitab alQawanin asySyar'iyyah dengan situasi sekarang. Ending tulisan ini menunjukkan bahwa konsep kafa'ah dalam perkawinan saripah dengan non-sayid menurut pemikiran Sayyid 'Us'man bin Yahya 
dalam kitab al-Qawanin asy-Syar'iyyah adalah tidak boleh atau haram, begitu pula dengan fatwa yang membolehkan perkawinan saripah dengan non-sayid. Sebagai argumentasi yang menguatkan pendapat Sayyid 'Usman adalah pendapat yang di ambil dari dua kitab yang berjudul Bugiyyah al-Musytarsyidin karya Sayyid 'Abdurrahman Ba'alawi dan Tarsyikhul Mustafdin Bitausihi Fath al-Mu'in karya Sayyid 'Alawi bin Ahmad al-Saqdf. Namun, dua pendapat ini lebih banyak dilatar belakangi oleh tradisi masyarakat Hadramaut ketika itu, dan Sayyid 'Usman sendiri hanya menerima hukum jadi yang diambilnya dari ulama terdahulu yang telah mengeluarkan fatwa lebih dulu, dalam hal ini tidak ada ijtihad baru yang dilakukan Sayyid 'Usman. Selain itu, Sayyid 'Usman juga mengemukakan beberapa hadis yang dijadikan sebagai dalil nash yang menguatkan pendapatnya, namun hadi-shadis ini sama sekali tidak berkaitan dengan konteks kafa'ah. Perkembangan selanjutnya, ternyata pemikiran Sayyid 'Us'man ini sudah tidak relevan lagi dengan situasi sekarang, disamping karena pemikiran Sayyid 'Usman lebih bersifat eksklusif, hal ini juga disebabkan karena keberadaan kafa' ah dalam suatu perkawinan tidak lain hanya untuk mencapai suatu keharmonisan dalam rumah tangga, sehingga ketentuan kafa'ah itu dapat berlaku sesuai dengan situasi dan kondisi masyarakatnya masing-masmg yang membutuhkan, tanpa harus memberatkan salah satu pihak dan jelas harus terlepas dari kepentingan pribadi.

Kata Kunci: kafa'ah, sarifah dan non-sayyid

\section{A. Pendahuluan}

Perkawinan merupakan ikatan perjanjian yang halal lagi suci, suatu ikatan yang menyatukan dua insan; laki-laki dan perempuan, menjadi sepasang suami istri dalam menempuh kehidupan rumah tangga yang selalu diharapkan kekal atau abadi selamanya. Maka sudah sepantasnya kedua calon suami istri dalam memilih pasangannya mencari yang sepadan atau sebanding dengannya dalam banyak hal, karena kesepadanan atau sebanding dalam memilih suami istri merupakan salah satu asas dalam membina keluarga muslim yang utuh dan harmonis.

Slamet Abidin dan Aminudin ${ }^{1}$, menyatakan bahwa kesepadanan atau kesesuaian dalam Islam dikenal dengan istilah "sekufu atau kafa'ah". Begitu pentingnya kafa'ah dalam perkawinan menyebabkan para fuqaha meletakan kafa' $a h$ sebagai salah satu syarat dalam perkawinan. Hanya saja, dalam penekananya para fuqaha mempunyai perbedaan pandangan, sehingga dengan adanya perbedaan pandangan ini mengakibatkan Kafa'ah dalam prakteknya sering disalahgunakan oleh sebagian orang dan terkadang bertentangan dengan makna (ruh/spirit) Islam yang tidak membedakan kelas, suku. bangsa, dan ras. ${ }^{2}$ Kendati pun demikian, berbagai pendapat masih saja muncul seiring dengan penentuan ukuran Kafa'ah tersebut. Sebagian pendapat ada, yang mengukur Kafa'ah itu hanya pada agamanya saja, tetapi ada pula sebagian pendapat yang mengukur Kafa'ah itu dari segi nasab/keturunan, harta, pendidikan, dan juga jasmaninya. Perbedaan-perbedaan inilah yang mengakibatkan timbulnya penentuan yang berbeda dalam

\footnotetext{
${ }^{1}$ Slamet Abidin dan Aminudin, Fiqh Munakahat I, (Jakarta: Pustaka Setia, 1999), hlm. 51.

${ }^{2}$ Khairuddin Nasution, "Signifikan Kafa'ah Dalam Upaya Mewujudkan Keluarga Bahagia", Jurna Aplikasi, Vol. IV No.1 Juni-2003, hlm.33
} 
menekankan ukuran Kajd'ah. Padahal ayat Alquran dan hadis telah menjelaskan bahwa ukuran $K a f a ' a h$ itu terletak hanya pada faktor agamanya saja dan tidak ada yang lain.

Melihat kenyataan seperti ini, ternyata perkara $K a f a ' a h$ dalam suatu perkawinan tidak bisa diabaikan begitu saja, ternyata para ulama juga menaruh perhatian besar terhadap perkara $K a f a^{\prime} a h$ tersebut. Pentingnya Kafa'ah ini, penulis lihat memang sangat berpengaruh besar dalam mewujudkan suatu rumah tangga yang harmonis sesuai dengan tujuan perkawinan itu sendiri. Betapa tidak, kesepadanan yang menjadi salah satu asas dalam berumah tangga memang sangat diharapkan bagi setiap calon suami istri. Dengan kata lain, penekanan Kafa'ah ini dimaksudkan untuk mengurangi banyaknya perbedaan antara suami isteri yang mungkin saja akan timbul di kemudian hari.

Menurut Zuraida Mohyin, Kafa'ah didefinisikan oleh para ulama sebagai al-Musawwan wal Muqarrab yang berarti persamaan atau kemiripan. Oleh karena itu, para ulama memandang penting adanya Kafa'ah ini lebih ditekankan kepada pihak perempuan dan bukan dari pihak lakllaki, sebab apabila seorang laki-laki beristeri dengan seorang perempuan yang lebih rendah derajatnya, hal ini tidak banyak menimbulkan permasalahan, karena sebagai seorang laki-laki, tentu ia malah akan mengangkat derajat isterinya menjadi lebih baik, lain halnya jika seorang perempuan yang bersuamikan dengan seorang laki-laki yang derajatnya lebih rendah dari dirinya, tentu perkara seperti inilah yang sering menimbulkan masalah dalam perkawinan. ${ }^{3}$

Oleh karena Kafa'ah ini lebih ditekankan pada pihak perempuan, maka penentuan Kafa'ah ini menjadi hak perempuan yang akan kawin, sehingga apabila dia akan dikawinkan oleh walinya dengan laki-laki yang tidak sekujil dengannya, maka dia dapat menolak atau tidak memberikan ijin untuk dikawinkan oleh walinya. Hal ini berarti bahwa seorang perempuan pun berhak memilih dan menentukan calon pendamping hidupnya kelak, sehingga beberapa faktor yang menjadi pertimbangan laki-laki dalam memilih perempuan sebagai isterinya juga berlaku bagi perempuan. Sebaliknya Kafa'ah h juga dapat dikatakan sebagai hak walinya yang akan mengawinkan, sehingga bila anak perempuannya kawin dengan laki-laki yang tidak sekufu, maka walipun dapat mengintervensinya yang untuk selanjutnya menuntut pencegahan berlangsungnya perkawinan. ${ }^{4}$ Adanya hak memilih dan menentukan calon Suami bagi seorang perempuan ini jelas terlihat dari hadis Rasulullah saw, yang memberikan kesempatan kepada seorang perempuan untuk memberi ijin ataukah tidak terhadap laki-laki yang akan meminangnya. Dalam hadis dari Abu Hurairah r.a, Rasulullah melarang menikahkan janda sebelum dia diminta persetujuannya dan gadis tidak boleh dinikahkan sebelum ia diminta izinnya". Para sahabat bertanya: Wahai rasulullah, bagaimana izinnya? ]awab Beliau : Tanda izinnya ialah diamnya". (H.R. Nasa'iy) ${ }^{5}$

3 Zuraida Mohyin. T.th. Sekufu dalam Perkawinan Elak Berbagai Masalah, http://www.mailarchive.com/hidayah.net@yahoogroups.com/msg05189.html (0nline 17 JUli 2009)

4 Amir Syaifuddin, Hukum Perkawinan Islam Di Indonesia Antara Fiqh Munakahata dan Undang-undang Perkawinan, (Jakarta: Kencana, 2006), hlm. 140

${ }^{5}$ Bey Arifin dan Yunus Ali Al-Muhdhor (Pent), Terjemah Sunan An-Nasa'iy, (Semarang: CV. Asy Syifa, 1993), 111.481. 
Hadis di atas menjelaskan bahwa seorang perempuan jelas memiliki hak memilih dalam dirinya, baik menerima ataupun menolak untuk dinikahi oleh seorang laki-laki. Sehingga terasa tidak adil jika hanya laki-laki saja yang diberi wewenang dalam memilih dan menentukan calon isterinya, sedangkan perempuan tidak. Terlebih-lebih jika hal ini dikaitkan dengan isu jender yang belakangan ini marak di perbincangkan, konsep Kafa'ah jelas berkaitan erat dengan kesamaan hak antara laki-laki dan perempuan dalam memilih calon pendamping hidupnya kelak.

Berbicara masalah Kafa'ah, lebih jauh penulis ingin mengemukakan suatu permasalahan yang menurut pengamatan penulis masih banyak terjadi dan berkembang di masyarakat hingga saat ini. Permasalahan ini tidak lain adalah menyangkut konsep Kafa'ah dalam perkawinan antara syarifah dan non-sayyid. ${ }^{6}$ Namun sebelumnya perlu dikemukan lebih dahulu bahwa seorang sayid itu adalah gelar yang ditujukan kepada laki-Iaki yang merupakan keturunan Rasulullah saw, dan saripah adalah gelar yang diberikan kepada perempuannya. ${ }^{7}$ Permasalahan yang muncul di kalangan mereka adalah tradisi perkawinan yang dilaksanakan secara turun temurun mengikuti nasab ${ }^{8}$ (keturunan) mereka, maksudnya mereka hanya akan menikah dengan orang yang sekufu dengan mereka saja (sayid dengan saripah dan saripah dengan sayid).

Namun demikian perlu ditekankan sekali lagi bahwa seorang sayid tidak ada kendala bila menikah dengan non-saripah, sehingga perkawinan sekufu itu tidak diharuskan bagi seorang sayid. Sebab, menurut kepercayaan mereka apabila seorang saripah menikah dengan non-sayid maka akan mengakibatkan putusnya nasab atau keturunan Rasulullah saw yang seharusnya dipelihara dan jangan sampai terputus. Perkara seperti inilah yang mereka anggap sebagai perkawinan yang tidak sekufu.

Konsep Kafa'ah ini secara spesifik tertuang dalam Kitab al-Qawanin asy Syar'iyyah karya Sayid 'Usman bin Yahya (1822 M-1916 M), yang telah ditulis pada tahun 1881 M atau 126 tahun yang lalu. Beliau memperlihatkan pandangan yang begitu keras terhadap konsep Kafa'ah dalam perkawinan saripah dan non-sayid, dengan menentang atau melarang adanya perkawinan antara saripah dan non-sayid, dan kalaupun perkawinan itu tetap terjadi maka hukumnya haram dan tidak sah. Pendapat Sayid 'Usman ini didukung oleh beberapa hadis dan dua kitab lain yaitu Bugiyyah al Musytarsyidin dan Tarsyikhul Mustafidin Hasyiah Fath al-Mu'in yang dijadikan dasar untuk penguat argumennya.

Urgensitas pemikiran Sayid 'usman relasinya dengan konsep kafa'ah sangat menarik untuk dijadikan objek kajian. Ditambah lagi jika pemikiran Sayid 'Usman ini dihubungkan dengan situasi sekarang, yang mana konsep Kafa'ah masih sangat mengakar dan terus berkembang di masyarakat. Sehingga akan dapat diketahui apakah pemikiran Sayid 'Usman ini masih relevan

${ }^{6}$ Kata "sayyid" dan "saripah" merupakan kata yang diadopsi dari bahasa arab yaitu "sayyid" dan "syarifah", sehingga ketika digunakan maka penulisannya pun mengikuti kaidah bahaa Indonesia yang umum digunakan, sesuai dengan apa yang terdapat di dalam Kamus Bahasa Indonesia.

7 Dewan Redaksi Ensiklopedia Islam, Ensiklopedi Islam, artikel "saripah", (Jakarta. PT. Ichtiar Baru van Hoeve, 1997), hlm 38.

8 "Nasab (keturunan atau kerabat) yaitu pertalian kekeluargaan berdasarkan hubungan darah, melalui akad perkawinan yang sahlm Ibid., artikel "nasab", hlm 13 
atau tidak untuk perkembangan selanjutnya. Maka tulisan ini mencoba memaparkan sketsa pemikiran Sayid 'Usman yang telah dituangkan dalam karyanya al-Qawdnin asy-Syar'iyyah.

\section{B. [Hasil dan Pembahasan]}

\section{Kafa'ah Dalam KITAB AL-QAWANINASY-SAR'IYYAH}

Mengutip pendapat" Martin Van Bruinessen, yang menyebutkan bahwa Sayid 'Usman bin Yahya adalah ulama Arab-Batavia yang terkenal dan merupakan ulama terakhir yang menulis kitab berpengaruh dalam bahasa Melayu. ${ }^{9}$ Penulisan kitab Al Qawanin Asy-Syar'iyyah Ii Ahli AI-Majalis AI-Hukmiyyati wa Al-lfta'iyyah ${ }^{10}$ tidak lain adalah untuk menyempurnakan Pengadilan Agama yang ketika itu pengetahuan Agama dan bahasa Arab para penghulunya sangat minim sekali ${ }^{11}$, sehingga kitab ini dijadikan panduan bagi Pengadilan Agama ${ }^{12}$. Sebab lain dari lahirnya kitab ini adalah bahwa Sayid 'usman merupakan seorang pembela yang gigih atas kemurnian darah sayid, sehingga ketika mendiskusikan persoalan Kafa'ah (kesepadanan) antara calon suami isteri, beliau menantang keras pernikahan antara saripah dan non-sayid. ${ }^{13}$ Kitab ini mengalami banyak cetak ulang dan dipakai lebih dari satu abad. ${ }^{14} \mathrm{~S}$

Sebuah karya biasanya mencerminkan buah pemikiran pengarangnya, oleh karena itu, untuk mengetahui pemikiran Sayid 'Usman dalam kitabnya Al-Qawanin Asy Syar'iyyah khusus mengenai konsep Kafa'ah, maka kiranya perlu untuk memberi gambaran tentang isi kitab tersebut. Kitab ini berukuran kecil (panjang :20 cm dan lebar $113 \mathrm{~cm}$ ), terdiri dari satu jilid dengan jumlah halaman sebanyak 128 halaman dan terdiri atas 40 pasal, serta menggunakan bahasa Melayu.

Sayid 'usman dalam pandangannya menyebutkan bahwa selain agama, keturunan (nasab) dan pekerjaan juga merupakan faktor penting dalam menentukan ukuran Kafa'ah. Hal ini dapat dilihat dari pemyataanya :

(Perkara Kafa'ah yakni pangkat manusia di dalam perkara berlaki isteri. Bermula tiada sah seorang beristeri kepada perempuan yang lebih pangkatnya dari padanya, lebih itu dengan bangsa atau pekerjaan melainkan jikalau dengan sukanya perempuan itu menjatuhkan pangkatnya beserta suka walinya yang $a q r a b)^{15}$

Berdasarkan pernyataan di atas, memberikan sinyalemen yang kuat terhadap pentingnya Kafa'ah dalam perkawman Selama agama yang memang sudah menjadi keharusan, nasab dan

\footnotetext{
${ }^{9}$ Martin Van Bruinessen, Kitab Kuning, Pesantren Dan Tarekat ..., hlm. 127.

10 " Selanjutnya iltulis Al-Qawanin Asy-Syar'iyyah

${ }^{11}$ Ibid.,

${ }^{12}$ Martin Van Bruinessen, Kitab Kuning, Pesantren Dan Tarekat ..., hlm. 127.

${ }^{13}$ Azyumardi Azra, Jaringan Global .., hlm. 144

${ }^{14}$ A. Mujib, lntelektualisme Pesantren ,... hlm. 42.

15 "Sayid usman bin Yahya, al-Qawani n asy Syar'iyyah, (Negeri Betawi Kampung Petumbuhan: Maktabah alSyekh Salim bin Sa'ad Nabhan 1317 H).hlm 65.
} 
pekerjaan juga ternyata menjadi sesuatu yang penting dan tidak boleh diabaikan begitu saja. Secara umum Sayid 'Usman mengatakan bahwa tidak sah seorang laki-Iaki beristeri dengan perempuan yang derajatnya lebih tinggi dari dirinya baik dalam hal keturunan maupun pekerjaan, kecuali jika perempuan itu suka begitu pula wali aqrab-nya (wali terdekat).

Dalam hal ini Sayid 'Usman tampaknya masih memberikan toleransi terhadap adanya perkawinan antara laki-Iaki dengan perempuan biasa, meskipun keduanya tidak se-kufu dalam hal nasab dan pekerjaan, dengan alasan jika perempuan dan wai aqrab-nya itu menghendaki. Isyarat ini nampak pada kalimat yang berbunyi "tidak sah seorang beristeri kepada perempuan yang lebih pangkatnya dari padanya, lebih itu dengan bangsa atau pekerjaan melainkan jikalau dengan sukanya perempuan itu menjatuhkan pangkatnya beserta suka walinya yang aqrab", ini berarti perkawinan tidak se-kufu itu akan menjadi sah apabila perempuan dan wali aqrab-nya itu menghendaki. Namun selanjutnya, toleransi ini tidak didapati lagi ketika dihadapkan dengan perkawinan antara saripah dan nons-ayid. hal ini dapat dilihat dalam sambungan tulisannya:

(melainkan jikalau syarifah maka tiada harus bagi lain dari pada bangsa sayid berlaki pada syarifah beserta suka walinya yang aqrab sebab karena itu menyakiti hati sekalian bangsa sayidahl al-Bait Rasulullah SAW dan menjadi penggoda besar kepada mereka itu maka dari karena yang demikian itu telah banyak ulama dari pada ahl al-Bait Nabi SAW yang tiada meharuskan yang demikian itu). ${ }^{16}$

Pernyataan yang diungkapnya di atas memberi gambaran tentang hukum Kafa'ah dalam perkawinan antara saripah dan non-sayid yaitu tidak boleh atau tidak sah (dalam istilah kebahasaan lain disebut haram), sekalipun si saripah dan walinya menghendaki. Alasan ketidakbolehan ini menurut Sayid 'Usman disebabkan karena akan menyakiti hati sekalian kaum sayid ahl aI-Bait Rasulullah saw dan menjadi penggoda besar bagi mereka Di samping itu menurutnya para ulama ahl al-Bait Rasulullah saw juga tidak memperbolehkannya.

Menanggapi hal ini, penulis melihat adanya isyarat Kafa'ah nasab yang begitu tampak pada pernyataannya yang secara tegas melarang adanya perkawinan antara saripah dan non-sayid, meskipun perempuan dan walinya menghendaki. Hal ini seakan-akan menggambarkan tentang pentingnya Kafa'ah nasab sama dengan pentingnya Kafa'ah agama. Sehingga didapati adanya dikotomi yang terjadi antara perkawinan perempuan dengan laki-laki biasa (bukan sayid dan saripah) dengan perkawinan antara saripah dan nonsayid yang tidak sekufu. Jika pada perkawinan antara laki-laki dengan perempuan biasa yang tidak se-kufu Yang awalnya tidak sah, berubah menjadi sah ketika perempuan dan wali aqrab-nya menghendaki, berbeda dengan perkawinan saripah dan nonsayid yang tidak se-kufu.

Selanjutnya, jika ditilik lebih dalam, Sayid 'Usman dalam pernyataannya tidaklah secara jelas menghukumkan haram atas perkawinan saripah dan non-sayid. Kenyataan ini didapati dalam larangannya yang hanya menggunakan kata "tiada harus" perkawinan sarifah dan nonsayyid, sehingga peryataan ini akan berkonotasi tidak memberatkan apabila dilanggar. Namun

\footnotetext{
${ }^{16} \mathrm{Ibid}, \mathrm{hlm} ., 65$
} 
demikian, penulis mencoba memahami bahwa maksud kata "tiada harus“ yang dipakai Sayid 'Usman ketika itu memang bermakna "haram".

Argumentasi Sayid 'Us'man ini diperkuat oleh pendapat Sayid Abdurrahman Ba'alawi dalam kitab karangannya yang berjudul Bugiyyah al Musytarsyidin yang sekaligus dijadikan Sayid 'Us'man sebagai dasar atau nash terhadap haramnya perkawinan antara saripah dan nonsayid. Secara rinci Sayid 'Usman mengutip pendapat Ba'alawi yang mengatakan bahwa:

(Bermula nas-nya dari kitab Bugiyyah al-Musytarsyidin 210 yang artinya: Dengan maksudnya bahwa tiada harus bernikah oleh yang lain dari pada bangsa sarip (syarif) kepada saripah (syarifah) sekalipun dengan sukanya saripah itu beserta suka walinya. Sebab tiap-tiap sayid ada empunya hak di dalam itu nasab baik wali yang dekat atau yang jauh. Sama saja yang dikata pada saripah itu atau yang jua kepadanya dan telah berkawin satu orang Arab yang bukannya sayid kepada saripah di negeri Mekah maka telah bangun sekalian sayid-sayid di Mekkah beserta segala ulama di Mekkah atas memfasakh-kan nikahnya itu dan demikian pula jatuhnya itu di lain negeri pula maka di karang oleh ulama dari pada bangsa sayid-sayid akan banyak kitab menerangkan tiada harusnya itu maka di fasakh kan pula nikahnya ltu maka sekalian itu karena cemburuan kapada turunan yang mulia jangan dapat dlhinakan maka sekalipun telah berkata fuqaha bahwasanya ltu sah maka karena bagi ulama-ulama bangsa ahlBait itu mempunyai ijtihad dan ikhtiar di dalam perkara syar'i yang tiada dldapati oleh lain-lain fuqaha. ${ }^{17}$

Pandangan Sayid Ba'alawi di atas sangat berpengaruh terhadap argumentasi Sayid 'Usman mengenai Kafa'ah. Ba'alawi dalam kitabnya secara jelas menegaskan bahwa sungguh sangat tidak dibolehkan adanya perkawinan antara saripah dan non-sayid, meskipun saripah dan walinya itu sendiri menghendaki. Hal ini terlihat dari pernyataan Ba'alawl yang dikutip oleh Sayid 'Usman bahwa di tanah suci Mekkah sendiri pernah terjadi seorang Arab (non-sayid) menikah dengan saripah, lalu para sayid bangkit menentangnya dengan dukungan para ulama dan mereka mencelanya hingga hampir terjadi kekerasan kalau tidak segera dipisahkan.

Bahkan menurut Ba'alawi lagi, peristiwa serupa juga pernah terjadi di negeri lain (luar Mekkah) dan para sayid juga serentak menentangnya. Dari kejadian itu, para ulama dari bangsa sayid segera mengarang beberapa kitab yang menjelaskan ketidakbolehan perkawinan saripah dan non-sayid dan jika itu terjadi, maka perkawinan harus segera di fasakh (dibatalkan). Kemudian, pada kutipan terakhir juga disebutkan bahwa sekalipun ada fuqaha yang menghukumkan sah atas perkawinan tersebut, tetapi bagi para ulama ahl al-Bait, mereka mempunyai ijtihad $^{18}$ dan ikhtiar sendiri atas perkara tersebut yang mana hal itu tidak didapati oleh para fuqaha lain.

\footnotetext{
${ }^{17}$ Sayid 'Usman, al Qawanin asy-Syar'iyyah, hlm 65-66

${ }^{18}$ Ijthad (Istilah berusaha dengan sungguh-sungguh), sedangkan dalam bidang fikih ijtihad berarti mengerahkan segala tenaga dan pikiran untuk menyelidiki (meng-istinbath-kan) hukum-hukum yang terkandung dalam AlQur'an. Lihat Dewan redaksi Ensiklopedia Islam, Artikel "Ijtihad", (Jakarta: PT. Icthiar Baru van Hoeven 1997), hlm. 55
} 
Dengan mengambil pandangan Sayid Ba'alawi diatas, maka nampak terlihat bahwa argumentasi Sayid 'Usman yang tidak memperbolehkan saripah kawin dengan non-sayid sematamata hanya mengikuti tradisi para ulama terdahulu, ${ }^{19}$ dalam hal ini Sayid Ba'alawi dan Sayid 'Alawi as-Saqaf. Hal ini dapat dimaklumi, karena Sayid 'Usman sendiri lama hidup dan menempuh banyak pendidikan di Hadaramaut, selain faktor keluarga, guru-gurunyapun banyak berasal dari Hadramaut dan bergelar saayid, sehingga jelas bagi Sayid 'usman untuk senantiasa menjaga kemurnian keturunannya.

Selain itu, memang sudah menjadi tradisi bagi orang Hadramaut yang sangat mengagungagungkan nasabnya, dibanding keturunan bangsa lain. Kebanggaan terhadap nasab inilah yang membawa adanya ketentuan Kafa'ah dalam perkawinan di antara mereka. Jika ini benar, maka jelas terlihat bahwa tradisi yang melekat erat ketika itu adanya gejala hukum yang sangat statis. Para ulama tidak ingin melakukan ijtihad baru yang lebih mempertimbangkan maslahat tetapi hanya menerima hukum jadi dari ulama terdahulu sebagai bentuk penghormatan. Selain itu, pernyataan ini juga memberi sinyalemen kuat bahwa para ulama ahl al-Bait memiliki ijtihad dan ikhtiar sendiri terhadap perkara Kafa'ah tanpa mengikuti pendapat fuqaha lain di luar mereka dan ini juga berarti adanya peng-eksklusifan diri dari orang lain.

Pada sisi lain, untuk mencari pembenaran atas tradisi keharusan saripah kawin dengan sayid, maka Sayid 'Usman mengemukakan argumentasi menarik yang dikutipnya dari pendapat Sayid 'Alawi bin Ahmad al-Saqaf dalam kitab Tarsyikhul Mustahdin Bitausihi' Fath al-Mu'i'n yang mengatakan:

(Dan telah memilih ulama-ulama Syarif Bani 'Alawi bin 'Ubaidillah bin Ahmad yang hijrah ke Hadramaut pada tahun 317. Dalam mengawinkan anak-anak perempuan mereka, mereka mengikuti mazhab Imam Ahmad bin Hanbal ra., yaitu dipandang rido seluruh keluarga yang dekat dan yang jauh sehingga ada muncul fasakh dari kerabatnya si perempuan. Seorang saudara laki-laki harus memfasakh dengan rido/persetujuan ayahnya, karena sesungguhnya orang mengawinkan yang tidak sekufu bagi mereka adalah suatu kecacatan)... ${ }^{20}$

Menanggapi hal ini selanjutnya Sayid ’Usman mengatakan bahwa:

(maka sesudahnya diketahui akan segala nash ini maka sebaiknya menjauhkan diri dari pada memfatwakan atau meharuskan nikah sarifah dengan lain dari pada bangsanya dengan sematamata mengambil dari umumnya nash fuqaha. ${ }^{21}$

(adapun lantaran yang menikahkan harusnya itu dua perkara, pertama bahwasanya yang demikian itu menyakiti hati sekalian bangsa sayid ahl al-Bait Rasulullah saw sebab tiap-tiap sayid ada empunya hak di dalam itu bangsa dan tiap mereka itu jika ia mengetahui bahwa seorang yang bukan sayid beristeri pada saripah maka niscaya masygul-lah hatinya dan tiadalah ia rida sekali bahwa dihinakan bangsanya itu dan memjadilah itu suatu penggoda besar

\footnotetext{
${ }^{19}$ L.W.C. van Den Berg, Hadramaut dan Koloni Arab Di Indonesia, Rahayu Hidayat (pent), Jakarta: INIS, 1989), jilid 3. hlm, 62

${ }^{20}$ Sayid 'Usman, al Qawanin asy Syar'iyyah, hlm. 66.

${ }^{21}$ Ibid.
} 
menyakiti atasnya maka demikian pula orang yang berfatwa harus bagi seorang yang bukan sayid bahwa bernikah pada saripah apabila ridanya itu beserta rida walinya yang akrab maka آذ ية menyakiti pada sekalian ahl al-Bait Rasulullah saw dan mehinakan mereka itu maka adalah yang demikian itu menjadi penggoda menyakiti pula atas zatnya Rasulullah saw dan atas zatnya sayidatina Fatimah r.a dan menimbulkan mereka keduanya dengan mehinakan anak buah keduanya)... ${ }^{22}$

Tampaknya dalam hal ini Sayid 'Usman mengikuti pendapat para ulama pendahulunya yang seakan-akan tetap mempertahankan budaya lama yang dianut oleh ulama-ulama Hadramaut, yaitu memelihara kemurnian keturunan Rasulullah saw yang sangat dibanggabanggakan dan dihormati. Akibatnya, tidak ada sesuatu yang baru yang bisa diambil dari argumentasi Sayid 'Usman sendiri Bahkan menurut Sayid 'Usman apabila kita telah mengetahui segala nash terlebih khusus lagi yang dikemukakan Sayid 'Alawi bin Ahmad al-Saqaf terdahulu, maka sebaiknya menghindarkan iri dari dan memfatwakan kebolehan adanya perkawinan antara saripah dan non-sayid. Alasannya menurut Sayid 'Usman adalah semata-mata mengambil fuqaha.

Melihat hal ini, penulis menganggap bahwa hendaknya segala fatwa yang dibuat oleh para ulama haruslah lebih dulu memperhatikan kemaslahatan dan tidak hanya mementingkan urusan pribadi terlebih lagi mempermasalahkan siapa yang berfatwa dan untuk siapa fatwa itu dibuat. Hal ini sesuai dengan kaidah yang berbunyi tasvarrufu al-mam 'ala ara'lyyati manuh-un bi al maslahah (tindakan imam terhadap rakyatnya harus dikaitkan dengan kemaslahatan).

Maksudnya bahwa hendaknya para ulama yang berfatwa terhadap masyarakat tidak hanya sekedar mengambil pada hukum yang telah ada lebih dulu tanpa mau mempertimbangkan apakah fatwa itu dapat memberi kemaslahatan orang banyak atau tidak. Apabila pada kenyataannya perintah itu sangat memberatkan dan bahkan bertentangan dengan kebiasaan masyarakat pada umumnya, maka jelas ini sangat tidak dibenarkan dan juga tidak sesuai dengan kaidah isti'mal an-nas hujjah yajibul al-amal biha (apa yang diperbuat orang banyak merupakan hujjah yang wajibb diamalkan).

Selanjutnya, jika menyimak argumentasi Sayid 'Usman di atas terdapat dua alasan tidak dibolehkannya perkawinan saripah dan non-sayid serta fatwa yang membolehkannya. Alasan tersebut adalah, pertama jika perkawinan ini terjadi maka hal ini akan menyakiti sekalian kaum Sayyid ahl al-Bait Raaulullah saw. karena tiap-tiap sayyid mempunyai hal dalam nasab-nya itu dan jika tiap-tiap mereka itu mengetahui seorang yang bukan sayid beristeri dengan saripah,

\footnotetext{
${ }^{22}$ Sayid 'Usman, al-Qawanin asy Syar'iyyah. hlm 66-67. Lihat Sayid 'Alawi bm Ahmad al-Saggaf, Tarsyikhul Mustaffidin Bitausihi Fath al-Mu'in, (Surabaya: Syirkah Bungkul. $t$ th). hlm 319 Dalam hal Ini. Sayid Usman tidak mengutip secara keseluruhan pendapat Sayid Alawi etapi hanya mengutip sebagian saja yang dianggapnya berhubungan dan dapat menunjang argumentasinya. Kibab Tarsyikhul Mustafidin Khasiyah Fath al-Mu'in ini sendiri ditulis pada tahun $1311 \mathrm{M}$, terpaut jauh dengan kitab karangan SSayid Usman al-Qawanin asy Syar'iyyah $1881 \mathrm{M}$.
} 
makamenurut keterangan di atas niscaya masygullah (sakitlah) hatinya (Rasulullah saw) dan tidaklah sekali-kali dia rida dihinakan nasab-nya itu. Alasan kedua, yaitu baik yang berfatwa maupun yang mengawininya, keduanya itu telah menyakiti sekalian ahl al-Bait Rasulullah saw dan Sayidah Fatimah r.a dan memurkakan keduanya sebab perbuatan ini dianggap telah menghinakan keturunannya.

Dengan demikian, alur pemikiran dalam fatwa larangan perkawinan saripah dengan pria non-sayid di atas terkait dengan dua hal, yaitu: pertama, nasab wanita saripah adalah nasab yang terunggul. sehingga tidak ada seorang pria mana pun selain kalangan sayid yang dapat menandingi derajatnya. Dalam perkara ini berlaku sistem patriakhal yaitu mengawinkan wanita saripah dengan pria non-sayid berarti memutuskan kemuliaan nasab yang dimiliki saripah, karena keturunan didasarkan pada garis keturunan ayah, bukan Ibunya atau bisa juga disebut konsep paternalitas yaitu garis keturunan yang berasal dari pihak ayah.

Oleh karena ltu. suatu kewajiban bagi para sayid untuk menjaga kemulian nasab ini, meskipun harus mengesampingkan kriteria-kriteria Kafa'ah lainnya. Kedua hak Kafa'ah wanita saripah adalah hak seluruh kaum sayid, baik dekat maupun secara keseluruhan, bukan hanya milik wali dan wanita itu saja. Oleh sebab itu mengawinkan mereka dengan pria non-sayid dianggap mempermalukan dan menghina seluruh kaum sayid serta menyakitkan hati mereka. sedangkan menyakitkan hati keturunan Rasulullah saw tidak diperkenankan karena sama halnya dengan menyakiti hati Rasulullah saw sendiri yang pada gilirannya dapat menyebabkan timbulnya murka Allah swt.

Hal terakhir yang dapat dicermati adalah argumentasi Sayid 'Usman yang didasarkan atas dalil nash keagamaan yang bersumber dari hadis yang dianggap memperkuat pemikirannya, hadis yang menyatakan betapa seorang menyakiti aku (Nabi Muhammad) dalam hal bangsa dan kerabatku, maka sesungguhnya orang yang menyakiti mereka sama halnya menyakitiku. Maka barang siapa yang menyakitiku maka ia memurkakan Allah SWT". ${ }^{23}$ Dan beberapa hadis yang semakna dengan hadis tersebut yang pada essensinya menyakiti keluarga Nabi sama dengan menyakiti Nabi Muhammad.

Sebelum mencermati lebih lanjut maksud hadis di atas, kiranya perlu penulis ungkapkan pendapat Muhammad 'Ajaj al-Khatib tentang Syahid al-Hadis. Menurutnya, Syahid al-Hadist adalah hadits yang diriwayatkan dari seorang sahabat, hampir sama dengan yang diriwayatkan dari sahabat lain, baik secara lafal maupun makna. ${ }^{24}$

Keberadaan Syahid al-Hadis ini, sengaja penulis gunakan tidak lain karena hadits yang dipakai Sayid Usman tidak ditemukan dalam kitab-kitab hadis. ${ }^{25}$ Sehingga penulis juga kesulitan

${ }^{23} \mathrm{Ibid}$.

${ }^{24}$ Munib. 'Takhrij Hadla Tentang Adab Buang Hajat", Makalah dlaampalkan dalarn Seminar Dosen Sekolah Tinggi Agama lslam (STAIN) Palangka Raya. 2001, hlm. 7

${ }^{25}$ Dalam hal ini kesulitan dan hambatan yang penulis temui ketika mencari hadist-hadist tersebut diperkirakan karena hadist yang dipakai Sayid Usman dalam kitabnya tidak mencantumkan perawi hadistnya secara tuntas dan jelas. 
untuk menilai kekuatan hadis tersebut. Sehingga berdasarkan adanya Syahid al-Hadits inilah penulis menggunakan hadis lain yang redaksi atau maknanya hampir serupa dengan hadis yang dipakai oleh Sayid 'Us'man. Hadis tersebut diriwayatkan dari Turmudzi yang bunyinya sebagai berikut:.

"Rasulullah saw bersabda: 'Takutlah kepada Allah swt dalam hal para sahabatku, jangan kamu jadikan mereka sasaran cercaan sepeninggalku. Barang siapa mencintai mereka maka dia mencintai mereka karena cinta kepadaku, dan barang siapa membenci mereka, maka dia membenci mereka karena benci kepadaku, dan barang siapa menyakiti mereka, niscaya menyakiti aku, dan barang siapa menyakiti aku niscaya menyakiti Allah swt dan barang siapa menyakiti Allah, niscaya Dia segera menyiksanya.(H.R Turmudzi) ${ }^{26}$

Kalau dicermati secara langsung, dalil yang digunakan Sayid 'usman di atas tidaklah berkaitan dengan tentang larangan perkawinan antara saripah dan non-sayid. Dengan kata lain konteks dalil hadits yang dikemukakannya hanya didasarkan oleh komitmen ulama Hadramaut yang di samping memang sangat kuat menjaga kemurnian keturunan Sayid, sekaligus juga memegang tradisi mengenai sarifah kawin dengan pria non-sayid yang dianggap mereka menyakiti sekalian kaum sayid dan sekalian ahl aI-Bait Rasulullah saw serta Fatimah.

Selanjutnya, sebagai konsekuensi dari pemikiran Sayid 'Usman ini, jika dibandingkan dengan beberapa imam maupun tokoh agama lain yang juga memandang penting kedudukan $k a f a ' a h$ dalam perkawinan akan memunculkan suatu wacana baru. Sudah pernah diungkap pada bab sebelumnya, bahwa sebagian besar fuqaha memandang Kafa'ah sebagai sesuatu yang penting dan harus diperhatikan dalam sebuah perkawinan. Pandangan mereka ini tanpa dasar yang kuat. Mereka mendasarkan pandangannya pada ayat maupun hadits yang mereka pahami sebagai dalil atau argumentasi hingga bertentangan antara Kafa'ah dalam surat Al-Hujurat (49) ayat: 13 .

Dasar pertama yang digunakan fuqaha sebagai pertimbangan Kafa'ah adalah firman Allah swt surat AlHujurat (49) ayat13. ${ }^{27}$ Menurut Qurais Sihab, penggalan pertama ayat di atas menegaskan bahwa semua manusia derajat kemanusiaannya sama di sisi Allah swt, tidak ada perbedaan antara satu dengan yang lain, baik antara laki-laki dengan perempuan, maupun antar suku, kasta maupun warna kulit. Pernyataan ini selanjutnya mengantarkan pada kesimpulan yang disebutkan pada penggalan terakhir ayat yakni "Sesungguhnya orang yang paling mulia di antara di sisi Allah ialah orang yang paling bertakwa", karena itu berusahalah untuk meningkatkan ketakwaan agar menjadi manusia yang termulia di sisi Allah, karena nilai ketakwaan sajalah yang bisa membedakan manusia satu dengan yang lain. ${ }^{28}$

\footnotetext{
${ }^{26}$ Mohammad Zuhri, dkk, Terjemah Sunan Turmudzi, juz V, (Semarang: CV. Asy syifa, 1992), hlm. 784

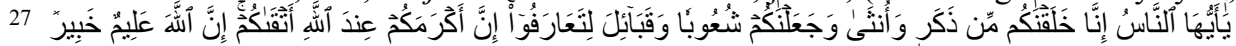

${ }^{28}$ Diriwayatkan oleh Abu Daud bahwa ayat ini turun berkenaan dengan Abu Hind yang pekerjaan sehari-harinya adalah pembekam. Nabi meminta kepada Bani Baydhah agar menikahkan salah seorang putri mereka dengan Abu Hind, tetapi mereka enggan dengan alasan tidak wajar mereka manikahkan putrid mereka dengan orang yang merupakan salah seorang bekas budak mereka. Sikap keliru ini dikencan oleh Allah dalam Al-Qur'an dengan
} 
Namun pada kenyatannya, manusia sering memiliki kecenderungan untuk mencari bahkan bersaing menjadi yang terbaik di luar nilai ketakwaannya. Banyak sekali manusia yang menduga bahwa memiliki materi, kecantikan serta kedudukan sosial baik karena kekuasaan atau garis keturunan, merupakan kemualiaan yang harus dimiliki dan berusaha keras untuk mendapatkannya, begitu pula dalam memilih pasangan dalam pernikahan. Padahal jika diamati kemuliaan yang dimaksud tidaklah abadi melainkan terkadang malah menyeret manusianya ke jurang kebinasaan. ${ }^{29}$

Menyimak dari penafsiran di atas, meskipun ayat tersebut tidaklah secara langsung dan spesifik beringgungandengan perkara $K a f a^{\prime} a h$, namun jika dilihat esensi yang disampaikan ayat di atas memberikan isyarat bahwa manusia itu samasatu dengan yang lain. Manusia tidak dibedakan atas dasar suku, garis sosial, keturunan, dan lain-lain karena yang membedakan hanya nilai takwanya saja. Hal ini tentu bersinggungan dengan perkara Kafa'ah perkawinan yang dipermasalahkan sejak awal. Betapa tidak, jika prinsip Kafa'ah begitu menuntut adanya kesamaan garis keturunan/kesukuan, pekerjaan, kekayaan, tanpa mengindahkan faktor agama sebagai sesuatu yang lebih penting, tentu ini sangat bertentangan dengan ruh Islam yang disampaikan melalaui ayat di atas, yang hanya membedakan manusia dari satu titik saja yaitu takwa. Sehingga sungguh tidak bijak apabila seseorang terlalu mempermasalahkan prinsip Kafa'ah di luar faktor ketaqwaan sebagai pondasi utama dalam berumah tangga dan lebih mengutamakan hal-hal keduaniawian saja, baik itu dengan alasan tidak kufu karena pekerjaan, kekayaan, keturunan, maupun kecantikannya. Dengan demikian sungguh beralasan kiranya jika fuqaha sepakat menjadikan ayat ini sebagai dalil atau penguat argumentasinya.

Dasar kedua yang dijadikan fuqaha sebagai dalil atau argumentasi konsep Kafa'ah adalah Hadis Rasulullah saw yaitu:

"Dari Musaddad dari Yahya dari Abdillah Berkata: menceritakan Sa'id bin Abi Sa'id dari ayahnya dari Abi Hurairah r.a. Rasulullah saw bersabda: Seorang wanita itu dinikahi karena empat perkara : karena harinya, karena keturunannya, karena kecantikannya, dan karena agamanya, maka kawinilah wanita karena agamanya, niscaya engkau bahagia". (H.R. Bukhari)

Menurut Ibnu Hajr Al-'Asqalan'i, walaupun hadis ini hanya diutarakan persyaratan atas perempuan, namun berlaku pula untuk laki-laki. Selanjutnya, isteri atau suami yang kuat imannya akan lebih terpercaya karena agamanya, dibanding mendapatkan pasangan yang kaya, rupawan maupun bangsawan, yang mana semua itu tidaklah abadi dan tidak menjamin

menegaskan bahwa kemuliaan disisi Allah bukan karena keturunan atau garis kebangsawanan tetapi karena ketakwaan.

${ }^{29}$ Quraish Shihab, Tafsir Al-Misbah..., hlm.267 


\section{Vol. 7, No.2, 2017}

ketenangan dalam rumah tangga. Oleh sebab itu rasa beragama itu haruslah jadi syarat utama dalam pemilihan calon pendamping. ${ }^{30}$

Dalam hal ini jika menilik pada prinsip Islam itu sendiri yang tidak ingin memberatkan umatnya, jelas juga berimplikasi pada konsep Kafa'ah yang diharapkan. Sehingga jika keberadaan hukum Kafa'ah masih terasa tidak mutlak sifatnya, maka sebaiknya dikembalikan kepada asal dari segala hukum yaitu tidak adanya beban, ini sesuai dengan kaidah yang berbunyi alaslu aI-'adam (Asal dari segala hukum adalah tidak adanya beban).

selanjutnya,menanggapi hadis di atas Ibnu Rusyd mengungkapkan bahwa terjadi silang pendapat antara fuqaha dalarn memahami maksud hadits di atas, sehingga hal ini pula yang membawa mereka berbeda dalam menentukan ukuran $K a f a{ }^{\prime} a h .{ }^{31}$ Namun diluar perbedaan itu, kiranya perlu penulis cantumkan satu hadis lagi yang disepakati fuqaha sebagai salah satu dalil dipertimbangkanya prinsip Kafa'ah sebagaimana yang diungkapkan oleh Sayid Sabiq. Hadis tersebut adalah:

"Rasulullah saw bersabda: "Apabila datang kepada kamu orang yang baik agama dan budi pekertinya, maka nikahkanlah (anak-anak perempuan) mu kepadanya. Jika kalian tidak melaksanakannya, niscaya akan terjadi fitnah dan kerusakan di muka bumi". Mereka (para sahabat) bertanya:"Apabila mereka tidak kaya? "Rasulullah saw bersabda: "Apabila datang (melamar) orang yang baik agama dan budi pekertinya kepada kamu maka nikahkanlah ia kepadanya". Nabi mengatakannya sampai tiga kali. (HR. Turmudzi).

Dalam kitab Tuhfah AI-Ahwazi yang merupakan Syarah Sunan at-Turmuzi disebutkan bahwa hadis di atas menekankan agama (akhlak dan pergaulannya) sebagai ukuran Kafa'ah dalam pemikahan Namun demikian, mazhab jumhur secara lebih luas mengukur Kafa'ah dalam empat hal yaitu Agama, Merdeka, nasab dan produktif. Namun agama diletakkan di urutan pertama dengan maksud karena Agamalah yang lebih utama dari yang lainnya. ${ }^{32}$

Selanjutnya Maftuh Ahnan juga menambahkan bahwa maksud hadis di atas adalah ditujukan kepada para wali (ayah dari calon pengantin perempuan), agar mereka mengawinkan anak-anak gadisnya atau siapa saja yang ada dalam perwaliannya, dengan seorang laki-laki yang datang melamamya adalah yang tekun beragama, baik dan jujur akhlaknya. Karena kalau hal itu tidak dilakukan, bahkan para wali lebih menyukai para pelamar yang berpangkat, yang ber-nasab dan berharta, sementara akhlaknya dan ketekunan agamanya melemah, maka akan terjadi

\footnotetext{
${ }^{30}$ Kahar Mansyur (pent), Bulughul Maram jilid 1l, (Jakarta: PT. Rineka Cipta, 1992), hlm. 6.

31 Muhammad lbnu Rusyd, Bidayatul Mujtahid wa Nihayatul Muqtashid, Pent. Imam Ghazali Said dan Achmad Zaidun, (Jakarta: Pustaka Amani, 2002), hlm. 427.

${ }^{32}$ Abdul Wahab bin Abdul Latif, Tuhfah AI-Ahwadzi, (Beirut: Darul Fikr, 1353), hlm. 204.
} 
berbagai macam fitnah dan kerusakan. Maksud kerusakan di sini diartikan adalah lebih pada hubungan horizontal sesama manusia.

Dari keterangan di atas jelaslah bahwa prinsip Islam dalam memilih jodoh ialah keteguhan dalam beragama dan berakhlak, sementara ukuran kemegahan, harta, nasab dan lain-lain tidaklah menjadi prioritas utama. Karena dalam pandangan Islam semua manusia itu adalah sama, tidak ada perbedaan satu dengan yang lain. Kelebihan antara seseorang dengan yang lain hanyalah didasarkan pada nilai takwanya masing-masing kepada Allah swt. Sehingga layak kiranya jika nilai ketakwaan ini dijadikan prinsip Kafa'ah dalam perkawinan.

Meskipun adanya perbedaan pandangan dan pemahaman yang mencolok antara Sayid 'Usman para fuqaha maupun tokoh agama lainnya, tapi di sini penulis dapat menarik satu benang merah bahwa tujuan dari pernikahan itu tidak lain adalah untuk mewujudkan keluarga yang utuh dan harmonis dengan bersandarkan agama sebagai penopang ketenangan rumah tangga. Bahwa memang tidak dipungkiri kesepadanan antara kedua pihak juga menjadi sesuatu yang sangat penting demi menyelaraskan alur pikir dan latar kehidupan keharmonisan berumah tangga. Namun ketika kesepadanan atau Kafa'ah ini begitu memberatkan dan menimbulkan kemudharatan salah satu pihak, alangkah terasa tidak adil jadinya. Oleh sebab itu penulis menilai bahwa keberadaan Kafa'ah dengan segala ketentuannya alangkah lebih baik diserahkan kepada pihak yang akan menikah beserta walinya, dengan syarat tidak memberi kemudharatan antara salah satu pihak, ini sejalan dengan kaidah Ad-dararu yuzal (kemudharatan harus dihilangkan).

Maksudnya jika suatu ketentuan itu mulai bersifat diskriminatif yaitu memaksakan seorang saripah harus kawin dengan sayid tanpa memberikan toleransi terhadapnya sedikitpun, hingga mengakibatkan dia dijauhkan dari perkawinan, apakah itu tidak memberi kesan yang sangat memberatkan hingga akhirnya memberikan kemudahratan bagi dirinya. Padahal Islam itu sangat mudah, ia tidak ingin sedikitpun memberatkan manusia, maka sudah sepantasnyalah kemudharatan itu harus dihilangkan.

Dan bahwa ketika kemudahratan itu dihilangkan, maka dengan sendirinya dapat ditarik sebuah kemudahan dari kesulitan yang terasa begitu menghimpit. Ini sejalan dengan kaidah almasyaqqalu lajlibu at-taisir (kesukaran itu dapat kemudahan).

\section{Kesimpulan}

Secara mikro bahwa konsep . Kafci'ah yang dibawa Sayid 'Usman terhadap larangan perkawinan saripah dan non-sayid sudah kurang relevan lagi dengan masyarakat sekarangDi samping karena adanya rasa ketidakadilan bagi seorang saripah yang ingin segera menikah sehingga terasa sedikit memberatkan juga karena tradisi ini sudah ditinggalkan sedikit demi sedikit.

Hal ini tidak terlepas dari tujuan pernikahan itu sendiri yang tidak lain hanya untuk mewujudkan rumah tangga tenteram dan bahagia. Ini berarti sekufu tidak selalu menjamin langgengnya hubungan suami istri dalam sebuah ikatan perkawinan. Adakalanya dengan adanya perbedaan, dapat mengisi kekurangan satu dengan yang lain hingga mampu hidup rukun dan bahagia asalkan keduanya mau saling menerima tanpa harus adanya syarat Kafa'ah yang begitu 
memberatkan bahkan sampai menghalangi maupun membatalkan sebuah perkawinan. Dalam Kompilasi Hukum Islam Pasal 61 disebutkan bahwa tidak sekufu tidak dapat dijadikan alasan untuk mencegah perkawinan, kecuali tidak sekutu karena perbedaan agama atau ikhtilaf ad-din.

Oleh karena itu ada baiknya jika ketentuan Kafa'ah lebih diarahkan kepada kemaslahatan semua pihak tanpa harus membedakan satu dengan yang lain kecuali dalam hal agama, karena agama merupakan pondasi awal dalam membina rumah tangga.

\section{DAFTAR PUSTAKA}

Abdullah, Wan Mohammad Shaghir, t.th. Sayyid Usman Betawi-Mufti Paling Masyhur. http://google/search:www.pikiranrakyat.com/teropong/sayyid+usman (online 07 Juli 2010).

Abidin, Slamet, dan Aminudin, Fiqih Munakahat I, Jakarta: Pustaka Setia, 1999.

Ahnan, Maftuh, dan Maria Ulfah, Risalah Fiqih Wanita, Surabaya: Terbit Terang, t.th.

Arifin, Bey, dan Yunus Ali Al Muhdhor (Pent.), Terjemah Sunan An Nasa'iy, juz 3, Semarang: CV, Asy Syifa, 1993.

Ayyub, Syekh Hasan, Fiqih Keluarga, Jakarta: Pustaka Al-Kautsar, 2005.

Azra, Azyumardi, Jaringan Global dan Lokal Islam Nusantara, Jakarta: Mizan, 2002.

Ba'alawi, Abdurrahman, Bugyah al-Musytarsyidin, Surabaya: a1Hidayah, t. th.

Berg, L.W.C. Van Den, Hadramaut Dan Koloni Arab Di Indonesia, jilid 3, Pent. Rahayu Hidayat, Jakarta: INIS, 1989.

Bruinessen,Martin Van, Kitab Kuning, Pesantren Dan Tarekat: Tradisi Indonesia. Bandung: Mizan, 1999.

Depag RI, Alquran dan Terjemahnya, Semarang: CV Al-Wa'ah, 1993.

Depdiknas, Ensiklopedi Nasional Indonesia, jilid 3, Jakarta: PT. Delta Pamungkas Pamungkas, 1997.

Dewan Redaksi Ensiklopedi Islam, Ensiklopedi Islam, Jakarta: PT. Ichtiar Baru van Hoeve, 1997.

al-Faqih Abulwalid Muhammad Bin Ahmad Bin Muhammad Ibnu Rusyd, Biddyatul Mujtahid Wa Nihayatul Muqtashid, Pent. Imam Gazali Said gian Ahmad Zaindun, Jakarta: Pustaka Amani, 2002.

al-Gadri, Hamdi, Politik Belanda Terhadap Islam Dan Keturunan Arab Di Indonesia, Jakarta: CV. Haji Masagung, 1988. 
Glasse,Cyril, Ensiklopedi Islam Ringkas, Edisi I, Pent. Chufron A. Mas'adi, Jakarta: Raja Grapindo, 2002.

Hamidy, Mu'ammal, dan Imron A. Manan, Terjemah Tafsir Ahkam Ash-Shabuni, Surabaya: PT. Bima Ilmu, 2003.

http://id.wikipedia.org/wiki/Hadramaut (online 03 agustus 2007).

Hurgronje, C. Snouck, Tulisan-Tulisan Tentang Islam di Hindia Belanda (jajaran pertama): Kumpulan Karangan C. Snouck Hurgronje, Pent. Soedarso Soekarno, Jakarta: INIS, 1992.

Ibnu Katsir, Terjemah tafsir Ibn Katsir, Pent. Salim Bahreisy dan Said Bahreisy, Surabaya: PT. Bina Ilmu, 1997.

Isa, Muhammad, bin Surah AtTurmudzi, Sunan Turmudzi, juz 5, Beirut/Lebanon: Dar al-Fikr, t. th.

Kuzari, Achmad, Nikah Sebagai Perikatan, Jakarta: PT. Raja Grafindo Persada, 1995.

Manan, Abdul, Reformasi Hukum Islam di Indonesia, Jakarta: PT . Raja Grafindo Persada, 2006.

Mansyur, Kahar (pent.), Bulughul Maram, jilid 11, Jakarta: PT. Rineka Cipta, 1992.

al-Maragi, Ahmad Mustafa, Tafsir AlMaragi, Pent. Bahrun Abu Bakar, Semarang: Toha Putra, 1993.

Mohyin, Zuraida, Sekufu dalam Perkawinan Elak Berbagai Masalah. http://www.mailarchive. com/hidayah.net@yahoog roups.com/msg05189.html (online 17 Juli 2006).

Mughniyah, M. Jawad, Fiqih Lima Mazhab, Jakarta: Lentera, 2004.

Mujib, A., dkk, Intelektualisme Pesantren: Potret Tokoh dan Cakrawala Pemikiran di Era Perkembangan Pesantren, Jakarta: Diva Pustaka, 2003.

an-Nasa'i, Abu Abdurrahman Ahmad, Sunan an-Nasa'i, Juz V, Beirut: Dar al-Fikr, 1930.

Nasution, Khairuddin, "Signifikansi Kafa'ah Dalam Upaya Mewujudkan Keluarga Bahagia", jurnal Aplikasi, Vol. IV No. 1 Juni2003.

Sayyid 'Alawi bin Ahmad al-Saggaf, Tarsyikhul Mustandin Khasiyah Fath al-Mu'in, Surabaya: Syirkah Bungkal, t. th.

Sayyid Sabiq, Fiqih Sunnah, Bandung: Al-Ma'arif, 1993.

Sayyid Usman bin Yahya, al-Qawdnin asy-Syar'iyyah, Negeri Betawi Kampung Petumburan: Maktabah al-Syekh Salim bin Sa'ad Nabhan, $1317 \mathrm{~h}$

Soemiyati, Hukum Perkawinan IslamDan Undang-Undang Perkawinan,Yogyakarta: Liberty, 1986. 
Steenbrink, Karel A., Beberapa Aspek Tentang Islam Di Indonesia abad ke19, Jakarta: PT. Bulan Bintang, 1984.

Syarifuddin, Amir, Hukum Perkawinan Islam Di Indonesia: Antara Fiqih Munakahat Dan Undang-Undang Perkawinan, Jakarta Kencana, 2006.

Zuhri, Mohammad, dkk, Terjemah Sunan Turmudzi, juz V, Semarang: CV. Asy Syifa, 1992.

Tim Penyusun Kamus Pusat Pembinaan dan Pengembangan, Kamus Besar Bahasa Indonesia, Edisi Kedua, Jakarta: Balai Pustaka, 1995.

Umar, Nasaruddin, Perspektif Jender Dalam AI-Qur'an, Tesis Program Pasca Sarjana. Tidak diterbitkan, Jakarta: IAIN Syarif Hidayatullah, 1999.

Wahab, Abdul, bin Abdul Latif, Tuhfah Al-Ahwadzi, Beirut/Lebanon: Darul Fikr, 1353 H. 